\title{
Strong Downslope Wind Events in Ammassalik, Southeast Greenland
}

\author{
M. Oltmanns AND F. STRANEO \\ Woods Hole Oceanographic Institution, Woods Hole, Massachusetts \\ G. W. K. MOORE \\ University of Toronto, Toronto, Ontario, Canada
}

\section{S. H. MERNILD}

Los Alamos National Laboratory, Los Alamos, New Mexico, and Centro de Estudios Científicios, Validiva, Chile

(Manuscript received 25 January 2013, in final form 9 September 2013)

\begin{abstract}
Ammassalik in southeast Greenland is known for strong wind events that can reach hurricane intensity and cause severe destruction in the local town. Yet, these winds and their impact on the nearby fjord and shelf region have not been studied in detail.

Here, data from two meteorological stations and the European Centre for Medium-Range Weather Forecasts Interim Re-Analysis (ERA-Interim) are used to identify and characterize these strong downslope wind events, which are especially pronounced at a major east Greenland fjord, Sermilik Fjord, within Ammassalik. Their local and regional characteristics, their dynamics and their impacts on the regional sea ice cover, and air-sea fluxes are described. Based on a composite of the events it is concluded that wind events last for approximately a day, and seven to eight events occur each winter. Downslope wind events are associated with a deep synoptic-scale cyclone between Iceland and Greenland. During the events, cold dry air is advected down the ice sheet. The downslope flow is accelerated by gravitational acceleration, flow convergence inside the Ammassalik valley, and near the coast by an additional thermal and synoptic-scale pressure gradient acceleration. Wind events are associated with a large buoyancy loss over the Irminger Sea, and it is estimated that they drive one-fifth of the net wintertime loss. Also, the extreme winds drive sea ice out of the fjord and away from the shelf.
\end{abstract}

\section{Introduction}

The Ammassalik region of southeast Greenland is well known for strong winds blowing off the ice sheet, which can be of hurricane intensity and cause severe destruction (Rasmussen 1989; Born and Boecher 2000; Mernild et al. 2008). These winds are called "piteraqs" and the strongest was observed on 6 February 1970, with estimated wind speeds of $90 \mathrm{~m} \mathrm{~s}^{-1}$ and temperatures of $-20^{\circ} \mathrm{C}$ (Born and Boecher 2000). While similar events occur in other regions along the coast, for example, in Kangerlussuaq north of Ammassalik (Bromwich et al. 1996), they are most prominent in Ammassalik, and thus piteraq is an Ammassalik term (Born and Boecher 2000).

Corresponding author address: M. Oltmanns, Woods Hole Oceanographic Institution, 266 Woods Hole Road, Woods Hole, MA 02543. E-mail: marilena@mit.edu
It means "sudden strong and cold wind, directed out of the fjord," where the fjord is Sermilik Fjord, a major east Greenland fjord in Ammassalik (Fig. 1).

Earlier studies have addressed the nature of the strong winds and found that they occur as a combination of different driving forces. The flow originates from the Greenland ice cap where the radiational cooling of the boundary layer results in a katabatic wind that accelerates over the steeper slopes at the coast (Rasmussen 1989; Parish and Cassano 2001; Parish and Bromwich 1987; Schwerdtfeger 1984; Heinemann 1999). The valley in Ammassalik and the steep topography around Sermilik Fjord channel the katabatic flow and intensify the wind speeds (Klein and Heinemann 2002; Bromwich et al. 1996; Heinemann and Klein 2002). Case studies have indicated that the boundary layer flow is supported by a synoptic-scale cyclone such that the geostrophic flow is in the same direction as the downhill topographic 


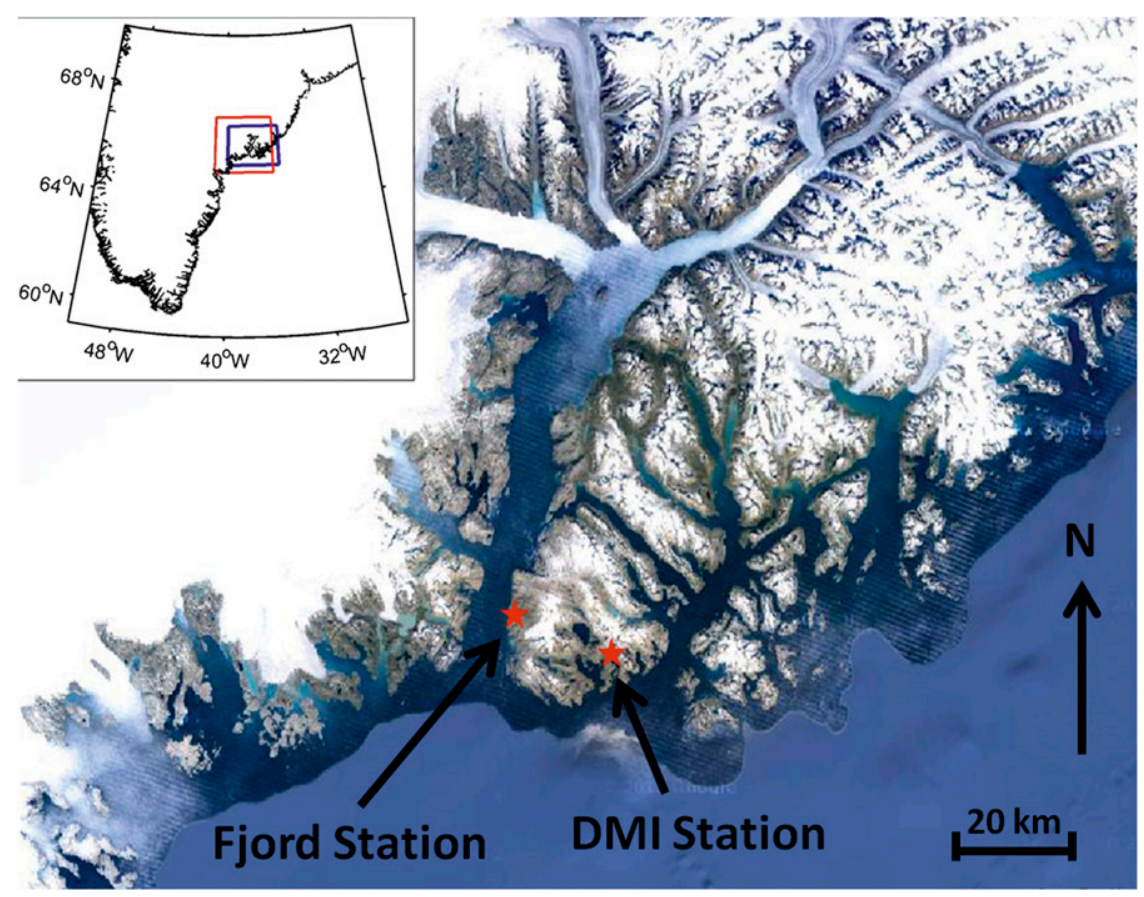

FIG. 1. Map of the Ammassalik area in southeast Greenland with the locations of the two meteorological stations at and close to Sermilik Fjord. The satellite image shown (googleearth.com) is from the region indicated by the blue box in the inset. The Ammassalik region, used in the text, is defined as the region within the red box shown in the inset.

gradient (Mills and Anderson 2003; Klein and Heinemann 2002; Heinemann and Klein 2002). Other case studies of downslope storms indicate the existence of mountain wave breaking (Doyle et al. 2005) and the creation of mesocyclones (Klein and Heinemann 2002). These results suggest the importance of a variety of forcings for individual downslope wind events, but to date there has been no generalized study of their characteristics, occurrence, and impacts.

In contrast, other high-speed wind events that occur in southeast Greenland have received much more attention. These include easterly and westerly tip jets (Doyle and Shapiro 1999; Våge et al. 2009; Moore and Renfrew 2005; Renfrew et al. 2009a; Outten et al. 2009) and barrier flows (Moore and Renfrew 2005; Petersen et al. 2009; Harden et al. 2011; Harden and Renfrew 2012; Moore et al. 2013) that result from the interaction of different synoptic situations with the Greenland topography (Moore 2003; Putnins 1970; Loewe 1972; Moore 2012). Tip jets are associated with large wind speeds around the southern tip of Greenland, whereas barrier winds are associated with large wind speeds at several locations along the east coast. Both types of wind events are linked with cyclones located east of southern Greenland but southward compared to the cyclone observed during piteraqs. While barrier winds are directed along the topographic barrier at the coast, the downslope winds studied here are parallel to the topographic gradient, and strong wind speeds are observed also over land, not only over the ocean.

One potential impact of downslope wind events (DWEs) is a large heat flux over the Irminger Sea, an important ocean convection region (Pickart et al. 2003b; Vage 2010) that contributes to the meridional overturning circulation (Jungclaus et al. 2005; Stouffer et al. 2006), the climate of northwest Europe (Vellinga and Wood 2002), and the sequestration of carbon dioxide by the deep ocean (Sabine et al. 2004). Deep ocean convection is an intermittent phenomenon triggered by winter storms that force large buoyancy losses (Marshall and Schott 1999). Previous studies have argued that it is affected by tip jets that are associated with large heat losses over the Irminger Sea (Våge et al. 2009; Pickart et al. 2003a), but to date no study has examined the impact of DWEs on convection or the heat loss over the Irminger Sea.

Furthermore, since DWEs are directed offshore, they can potentially advect sea ice offshore (Bromwich and Kurtz 1984) with a possible feedback on the wind intensity owing to the resulting air-sea interaction (Gallée 1997; Pettré et al. 1993). Indeed, numerical simulations of specific events in Ammassalik have confirmed this feedback (Heinemann 2003). Apart from impacting the ecology by creating coastal polynyas, the removal of sea 
ice away from the coast could lead to local freshening of the Irminger Sea. The removal of sea ice, moreover, might not be confined to the shelf region but could extend into Sermilik Fjord with possible effects on Helheim Glacier, a large Greenland glacier that drains into Sermilik Fjord. In fact, several authors have found a connection between the movement of outlet glaciers and the existence of a dense sea ice and iceberg cover (ice mélange), which exerts back pressure on the glacier and inhibits calving (Amundson et al. 2010; Howat et al. 2010; Walter et al. 2012). Thus, if DWE remove the local sea ice cover in Sermilik Fjord, they could contribute to the destabilization of Helheim Glacier.

Here, we present the first systematic study of DWEs in Ammassalik in southeast Greenland (Fig. 1). We combine meteorological station data from 1958 onward and an atmospheric reanalysis product to identify DWEs, describe their general characteristics, and investigate their dynamics. We then examine their impact on the buoyancy flux over the Irminger Sea and on the sea ice inside Sermilik Fjord and on the shelf. Section 2 describes the datasets. Section 3 gives an overview of the mean wind fields in Greenland, specifically Ammassalik, and explains our technique in identifying DWEs. Section 4 presents the results, which are discussed in section 5 .

\section{Data}

We use three different datasets to identify and characterize DWEs. Two of them are meteorological stations, and the other one is the European Centre for Medium-Range Weather Forecasts (ECMWF) Interim Re-Analysis (ERA-Interim) product. One of the stations is located on a hill in Sermilik Fjord (Fig. 1) at $65^{\circ} 40.8^{\prime} \mathrm{N}, 37^{\circ} 55.0^{\prime} \mathrm{W}$ at a height $25 \mathrm{~m}$ above sea level: its official name is Station Coast. The station was established by the University of Copenhagen in June 1997 and monitors meteorological conditions at a 3-hourly interval prior to 21 August 2007 and a 10-min interval thereafter (Mernild et al. 2008). Since 8 August 2008, there has been a duplicate station in case of failure of the primary. When data from one station are not available, they are replaced by data from the other. No data are available from 28 June to 6 August 2006 and from 29 May to 20 August 2007. Every observed time series from the stations was manually detailed, analyzed, and compared to observations from other stations in the region, to make sure that observational errors were eliminated from the dataset. In the following, we will refer to this station as the fjord station.

The other meteorological station is in Tasiilaq, a town near the fjord (Fig. 1). It has been operated by the Danish Meteorological Institute (DMI) since 1958 and is located at $65^{\circ} 36^{\prime} \mathrm{N}, 37^{\circ} 37^{\prime} \mathrm{W}$ at $53 \mathrm{~m} \mathrm{MSL} .^{1}$ Several small shifts of the station location occurred during the period of operation, but we did not find any discontinuities in the dataset. Data were recorded at a 3-hourly interval before 5 August 2005 and hourly interval thereafter. During this last period some data gaps exist but in most cases they are limited to a few days. The data are distributed and quality controlled by the DMI (Carstensen and Jorgensen 2010; Cappelen 2011). In the following, we will refer to this station as the DMI station.

To gain insight into the three-dimensional structure of the atmospheric flow, we use output from the atmospheric reanalysis model ERA-Interim from the ECMWF. The data have a 6-hourly temporal resolution since 1979 and a spatial resolution of $0.75^{\circ}$ in both horizontal directions with 60 levels in the model's terrain-following vertical coordinate that have been interpolated to pressure levels for use in this study (Dee et al. 2011).

Several studies have favorably compared ERAInterim to observations in that region. In October 2008 a comparison with data collected over the Irminger Sea from the Research Vessel (R/V) Knorr (KN194-4) was undertaken to verify the ERA-Interim product. The overall conclusion is that close to the surface ERAInterim represents winds very well. Especially the pressure is in excellent agreement with the observations (Harden et al. 2011). During high winds the $10-\mathrm{m}$ winds are underrepresented by $\sim 1 \mathrm{~ms}^{-1}$ and the 2 -m air temperature has a cold bias of $\sim 2^{\circ} \mathrm{C}$. Dropsonde measurements have been compared to the vertical structure of the ERA-Interim output (Harden et al. 2011; Renfrew et al. 2008), and it was found that, even though the basic structure of the wind and the temperature field is captured, ERA-Interim tends to underestimate the strength of gradients during high wind speed conditions. Over the Greenland ice sheet, the 10-m wind field was compared to observations from automated weather stations (Moore et al. 2013). The agreement was good with rms errors of $\sim 1 \mathrm{~m} \mathrm{~s}^{-1}$ and correlations of $\sim 0.65$. ERA-Interim temperature profiles were compared to radiosonde data in a study about surface-based inversions of the Arctic boundary layer with the overall conclusion that the data agree reasonably well with the ERA-Interim output (Zhang et al. 2011). To understand how well ERA-Interim describes DWEs over water we

\footnotetext{
${ }^{1}$ Before 31 March 1982 , it was located at $65^{\circ} 36^{\prime} \mathrm{N}$ and $37^{\circ} 38^{\prime} \mathrm{W}$ at $36 \mathrm{~m}$ MSL. After that date it was moved to $37^{\circ} 37^{\prime} \mathrm{W}$ at the same latitude but at a height of $50 \mathrm{~m}$ MSL, less than $1 \mathrm{~km}$ away from its original location. On 15 August 2005, it has been raised to $53 \mathrm{~m}$ MSL.
} 
compared its output to Quick Scatterometer (QuikSCAT) satellite data. We used the 2011 reprocessed QuikSCAT ocean wind vectors with an improved geophysical model function (Ricciardulli and Wentz 2011), which we obtained from Remote Sensing Systems, Santa Rosa, California. We found that the structure of the wind field during the events was in good agreement but that ERAInterim underestimates the peak wind speeds by approximately $1-2 \mathrm{~m} \mathrm{~s}^{-1}$ in the region of the peak wind speeds. ERA-Interim heat fluxes have successfully been used in other studies (e.g., Moore et al. 2012; Renfrew et al. 2009b). Based on the fact that the flux data are regularly subject to comprehensive verification and that they confirmed results from earlier studies, it was concluded that the ERA-Interim fluxes can be considered reliable and robust (Petersen and Renfrew 2009). DWEs have a comparatively small scale and very high wind speeds, however-two conditions in which reanalyses often have problems (Renfrew et al. 2009b). Thus, it is likely that the ERA-Interim heat fluxes are a lower bound for the actual heat fluxes but should still provide a good estimate.

The three datasets are complementary in a number of ways. The fjord station measures the winds directly inside the fjord valley where downhill winds are focused, and we expect the wind speed to be highest. The DMI station is only $16 \mathrm{~km}$ away from the fjord station but not directly inside the valley. Thus, we expect the winds to reflect more the large-scale topographic gradient. The main advantage of the DMI station dataset is its long time span from 1958. The ERA-Interim product provides information on the large-scale flow pattern even though we do not expect it to resolve the fjord, but it provides a good spatial data coverage in and around Ammassalik as well as the synoptic-scale atmospheric context.

To investigate the impact of the winds on sea ice we use a sea ice concentration product provided by the National Snow and Ice Data Center (NSIDC). It is obtained from the Advanced Microwave Scanning Radiometer for Earth Observing System (AMSR-E) on board the National Aeronautics and Space Administration Earth Observing System (EOS) Aqua satellite (Cavalieri et al. 2004). The level 3 gridded $89-\mathrm{GHz}$ brightness temperatures have been processed by the University of Hamburg to calculate sea ice concentration with a resolution of $6.25 \mathrm{~km}$ (Spreen et al. 2008). The record starts in June 2002, ends in September 2011, and has a daily resolution. We use the sea ice concentration for a confined region along the southeast Greenland coast (Fig. 10). Since the presence of sea ice in this region is restricted to the months January-May, we limit the analysis of the impact of DWEs on sea ice to this period.

\section{Method}

We begin by looking at the mean wind field over Greenland in ERA-Interim to understand the winds in Ammassalik (see Fig. 1 for location) in a large-scale context. We focus on the winter months (NovemberApril) since the synoptic situation during winter and summer is generally different and high wind speed phenomena, including the DWE studied here, tend to occur during winter (e.g., Våge et al. 2009; Moore and Renfrew 2005; Harden et al. 2011). In addition, the radiational cooling is more pronounced during winter and the passage of cyclones more frequent, which could potentially be important (Mills and Anderson 2003; Klein and Heinemann 2002; Heinemann and Klein 2002). Specifically, we examine where the mean $10-\mathrm{m}$ surface winds follow the topographic gradient and how they are influenced by the mean sea level pressure field. We note that there is large topographic gradient around Ammassalik that includes a valley that becomes narrower toward the coast (Fig. 2). While Sermilik Fjord itself is not resolved, the steep large-scale topographic gradient southwest of it is.

Over the ocean, the mean winds closely follow isobars, which are largely associated with the Icelandic low (Fig. 2). Above Greenland the geopotential is usually high, which gives the wind field an anticyclonic orientation. The east Greenland coast (including Ammassalik) separates the low from the high geopotential. In this region, the mean wind field is not purely geostrophic but slightly distorted as the winds tend to be downslope and down the pressure gradient. Also, the directional constancy [defined as the ratio of the speed of the mean winds to the mean wind speed (Moore 2003; Parish and Cassano 2003)] is large along the coast, indicating that the winds are directed downslope most of the time. At the DMI station the directional constancy is considerably smaller $(\sim 0.23)$, indicating that the wind direction varies on scales (temporal or spatial) not resolved by ERA-Interim (Table 1). The fjord station records a larger directional constancy $(\sim 0.74)$. At the DMI station the mean wind direction is northwesterly and at the fjord station it is northeasterly. We suggest that the mean directions are imposed by the direction of the topographic gradient at the location of the respective station.

Wind speed distributions are often described by a Weibull distribution (Hennessey 1977; Palutikof et al. 1999; Pavia and O'Brien 1986). The Weibull distribution is characterized by its shape and its scale parameter. While the scale parameter is proportional to the mean wind speed, the shape parameter determines the shape of the distribution. For instance, a shape parameter of 3.6 indicates a Gaussian distribution, while exponential 
a)
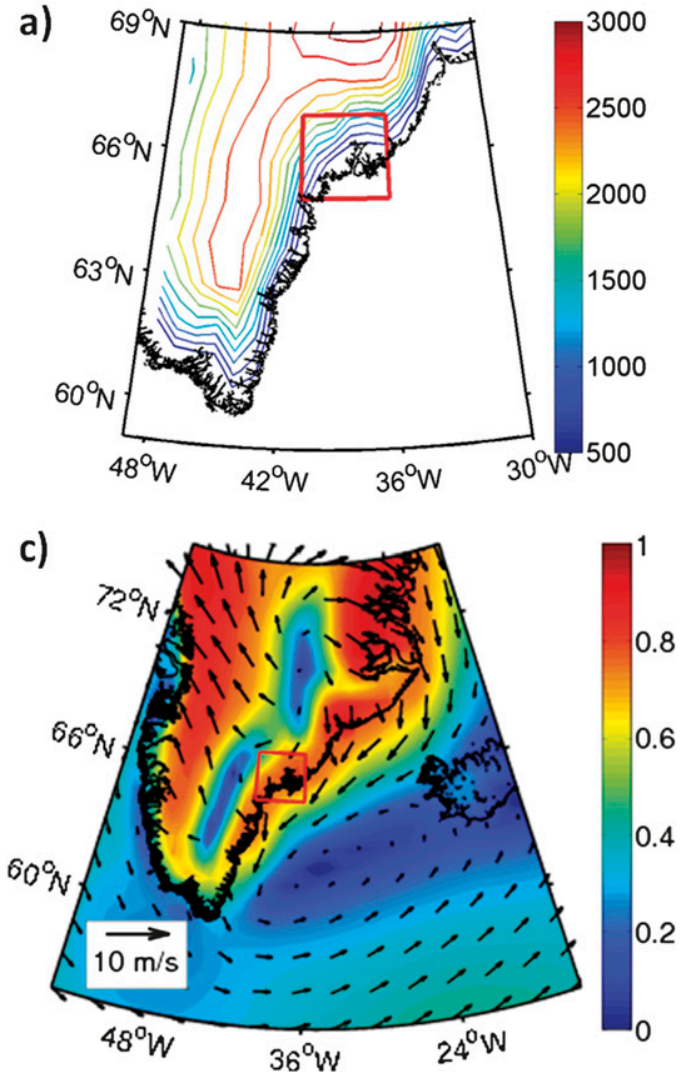

b)

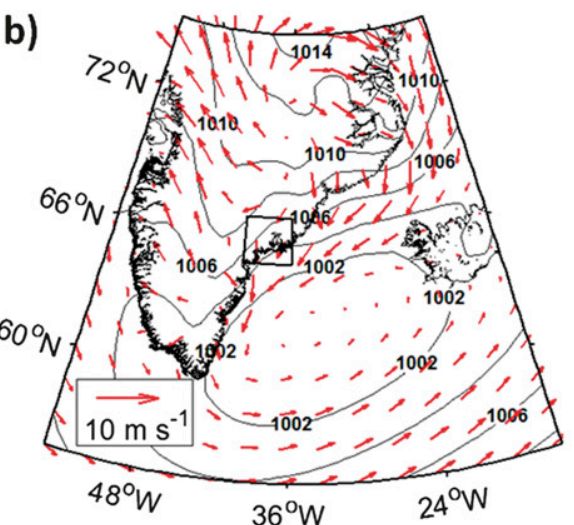

d)

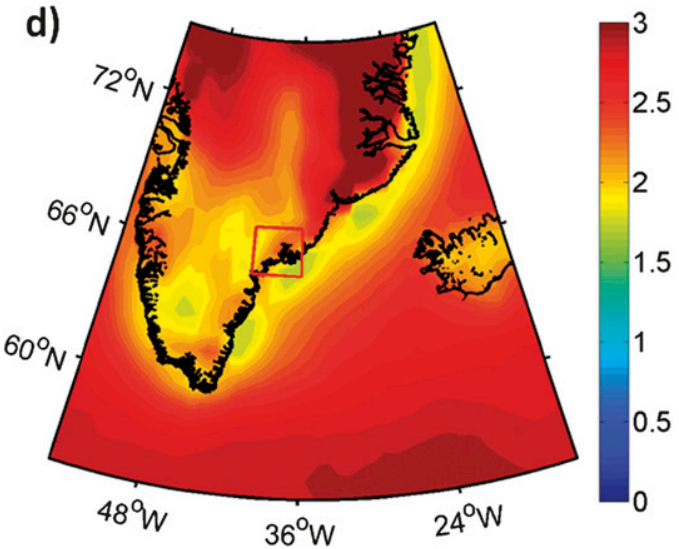

FIG. 2. (a) Surface elevation (m) and (b) mean SLP field (hPa) with the mean 10-m surface winds (November through April) from ERA-Interim. The winds tend to follow isobars, but in the Ammassalik they are directed across isobars from high to low pressure and downslope. (c) Directional constancy with mean 10-m surface winds (also from ERA-Interim). In Ammassalik, as well as in many other coastal regions, downslope winds (with a rightward deflection) are very common. (d) Shape parameter from the Weibull distribution. The low shape parameter along the southeast Greenland coast indicates a skewed wind speed distribution with many low wind speeds and few very high wind speeds. The red box delineates the region referred to as Ammassalik.

distributions have a shape parameter of 1 , and Rayleigh distributions have one of 2 . A shape parameter of less than one indicates a monotonically decreasing distribution. Figure 2 displays the shape parameter for the wind distribution in Greenland. It is small around Ammassalik, indicating that the local wind speed distribution is skewed: there are many winds with low speeds and a long tail of large wind speeds. Small shape parameters were also found in Coats Land, Antarctica (Renfrew and Anderson 2002). In this region it was found that winds are predominantly katabatic $40 \%-$ $50 \%$ of the time, while at other times the flow was due to other driving forces such as a synoptic-scale low pressure system (Renfrew and Anderson 2002). A summary of some statistical parameters describing the wintertime winds in the different datasets is given in Table 1. The shape parameter of the mean winds is even lower in the other two datasets (1.23 at the DMI station and 1.26 at the fjord station), indicating that the skewness of the wind distribution is even more pronounced. It is these high speed winds that we investigate in the rest of this study.

To build a composite of DWEs we followed the general criterion that they be downslope and strong. Owing to the different locations and characteristics of the three datasets, the specific definitions in each of them are, however, slightly different (Table 2). The identification of the wind events in ERA-Interim is based on the DMI

TABLE 1. Statistical parameters (mean with standard deviation) of the winds recorded by the meteorological stations from November through April. The mean is taken from 1998 to 2012 for the fjord station and from 1958 to 2012 for the DMI station.

\begin{tabular}{lcc}
\hline \hline & DMI station & Fjord station \\
\hline Mean wind speed $\left(\mathrm{m} \mathrm{s}^{-1}\right)$ & $2.60 \pm 3.48$ & $5.21 \pm 3.77$ \\
Mean wind direction $(\mathrm{deg})$ & $305.76 \pm 74.67$ & $58.52 \pm 53.88$ \\
Directional constancy & 0.23 & 0.74 \\
Shape parameter & 1.22 & 1.38 \\
\hline
\end{tabular}


TABLE 2. Definitions of DWE in the three different datasets. Other definitions give qualitatively the same results.

\begin{tabular}{llcc}
\hline \hline & \multicolumn{1}{c}{ Fjord } & DMI & ERA-Interim \\
\hline $\begin{array}{l}\text { Time span } \\
\begin{array}{c}\text { Direction condition, } \\
\text { clockwise (deg) }\end{array}\end{array}$ & $\begin{array}{l}1998-2010 \\
\text { none }\end{array}$ & $\begin{array}{c}1958-2010 \\
270-20\end{array}$ & $\begin{array}{c}1979-2010 \\
270-20\end{array}$ \\
$\begin{array}{c}\text { Speed condition } \\
\left(\mathrm{m} \mathrm{s}^{-1}\right)\end{array}$ & $>17.4$ & $>14$ & $>10$ \\
$\begin{array}{c}\text { Mean number of } \\
\text { events per year }\end{array}$ & $7.8 \pm 3.1$ & $7.6 \pm 3.2$ & $6.9 \pm 2.9$ \\
\hline
\end{tabular}

station location. This does not coincide with the location where ERA-Interim records the fastest winds during a DWE but using this location results in a better agreement in terms of the obtained wind events. However, alternative locations in Ammassalik give qualitatively the same results.

At the fjord station wind speeds above $5 \mathrm{~m} \mathrm{~s}^{-1}$ are usually only reached by winds in the along-fjord direction. Winds from other directions are blocked by the mountains surrounding the fjord. To capture only the strongest winds, we define an event as having a speed greater than the mean plus four standard deviations. For the time period from 1998 to 2010, this speed condition is $17.4 \mathrm{~m} \mathrm{~s}^{-1}$. Requiring the events to be at least $48 \mathrm{~h}$ apart so as not to count an event twice, this results in an average of 7.8 events per winter. The speed limit is arbitrary, but alternative definitions do not change the results qualitatively, only the number of obtained events differs.

In the other two datasets, the strongest winds have two preferred directions. Of the two, downslope winds are parallel to the topographic gradient in Ammassalik. Based on previous studies we identified the winds with the other direction as barrier winds, which are directed along the coast (Moore and Renfrew 2005; Petersen et al. 2009; Harden et al. 2011). In addition, we confirmed that most of the DWEs identified in the fjord data have the downhill direction in the other two datasets. Downslope winds at the DMI station are southeastward (between $300^{\circ}$ and $360^{\circ}$ in geographical coordinates), even though the winds have a clear north-to-south orientation in the data from the fjord station. We hypothesize that the difference in direction of $0^{\circ}-60^{\circ}$ is due to differences in the local topographic gradient between the fjord and the DMI station area.

To separate the downslope winds from the barrier winds, we apply a speed and a direction condition to the winds in ERA-Interim and the DMI station data. Wind directions need to be between $270^{\circ}$ and $20^{\circ}$ (clockwise). The number of events obtained this way is not sensitive to the direction condition because they naturally fall
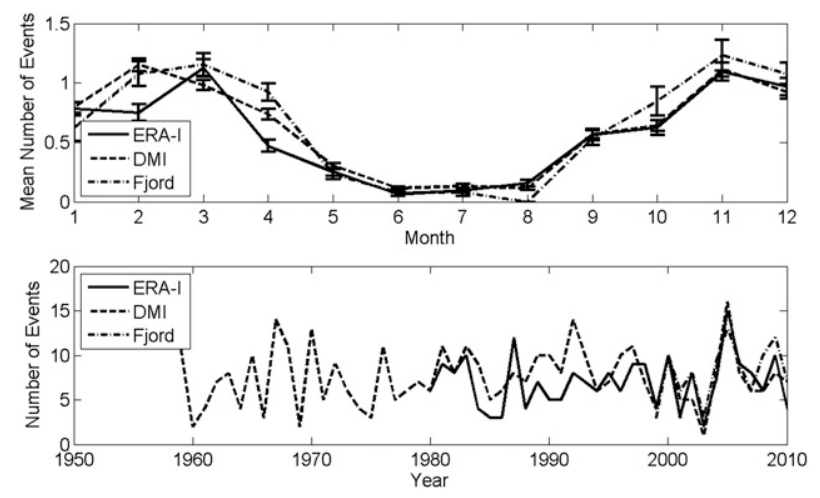

FIG. 3. (top) Mean number of events per month starting in January and (bottom) number of events per year obtained with the two meteorological stations and ERA-Interim. Error bars are represented by the standard error of the mean. DWEs occur mainly in the winter months and have a large interannual variability. Note that a year is defined to extend from July to the following June so as not to split the winters.

into a very narrow direction range. Thus, a direction condition between $300^{\circ}$ and $360^{\circ}$ (or $180^{\circ}-20^{\circ}$, which just filters out the barrier winds) gives qualitatively similar results. The condition on speed, which is $10 \mathrm{~m} \mathrm{~s}^{-1}$ in ERA-Interim and $14 \mathrm{~m} \mathrm{~s}^{-1}$ at the DMI station, affects the number of DWEs obtained. We chose the above limits so that we capture approximately the same number of DWEs in the common time period, which is about seven events per year. The comparatively smaller speed limit in ERA-Interim is likely related to the coarse resolution of the model. As shown below, the DWEs captured with these slightly different definitions have similar composites and share about $70 \%$ of the obtained events. The wind events obtained by the fjord station only are recorded by the DMI station and ERA-Interim as either downslope winds that are not fast enough to fulfill the condition on wind speed or as very strong barrier winds.

\section{Results}

\section{a. Characteristics}

The seasonal distribution of events obtained is similar in all three datasets (Fig. 3). The bulk of the events occur between October and April with peaks in FebruaryMarch and November with a large interannual variability (Fig. 3). We use all of the obtained DWEs to build a composite of wind speed, sea level pressure, and temperature in each dataset (except for sea level pressure from the fjord station where it is not measured). Whenever we refer to wintertime wind events or winter climatology, we define wintertime as the months November-April. Figure 4 shows the evolution of these 

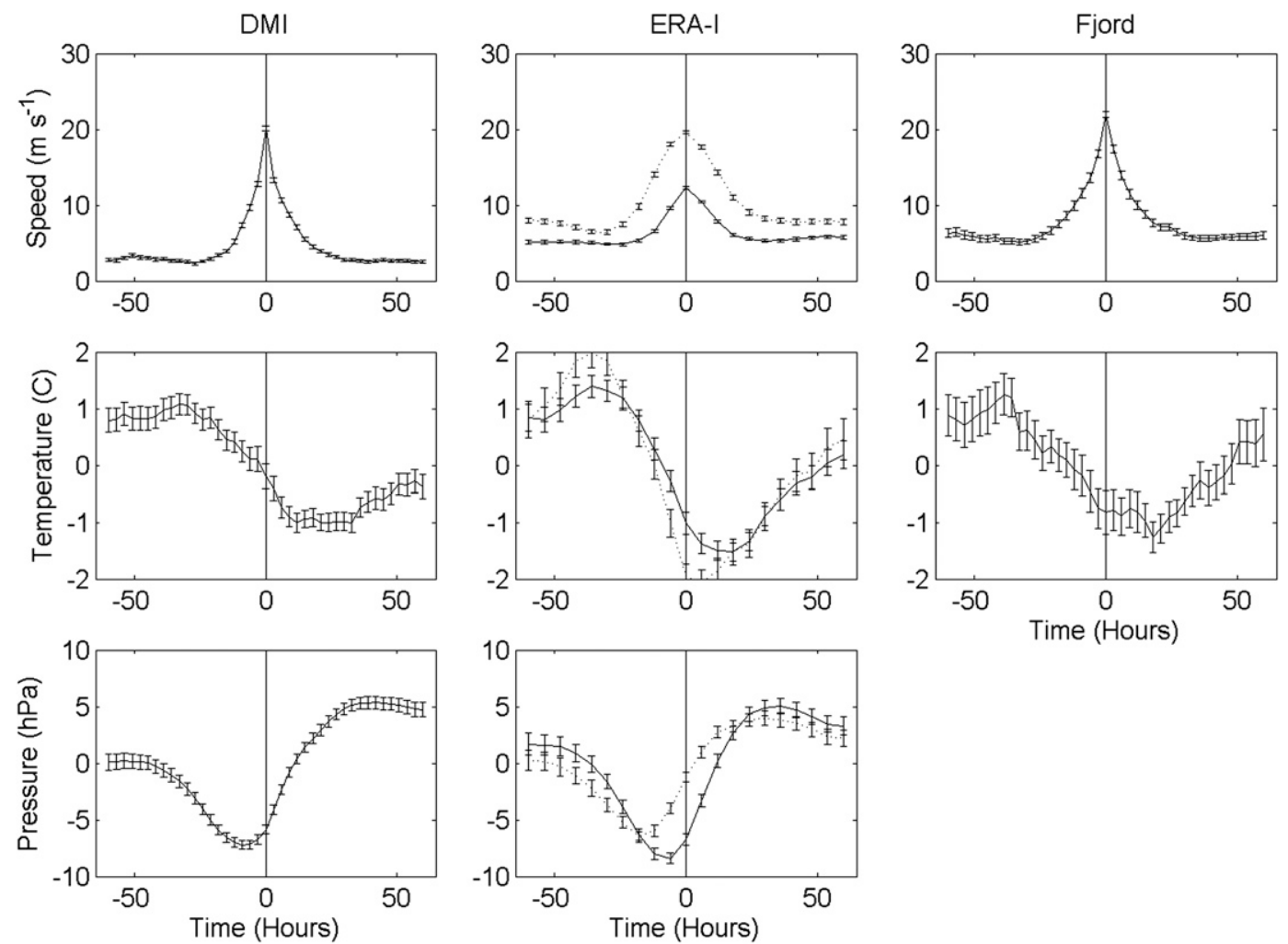

FIG. 4. Composite of speed, temperature, and pressure evolution in the DMI data, the fjord data, and in ERAInterim. Negative time means time before the time of maximum wind speed. Error bars are represented by the standard error of the mean. The solid line in the ERA-Interim panel is based on the DMI station location. The dotted line is based on the location where the wind speed in ERA-Interim is strongest, which corresponds to the cross section of the two sections shown in Fig. 5. Downslope wind events feature a distinct drop in pressure and temperature.

surface fields from one day before the time of maximum wind speed until one day afterward. The origin $(0 \mathrm{~h})$ is defined as the time of maximum wind speed and negative time means time before the wind speed reaches its maximum. To derive the anomaly (of temperature and pressure), we subtract the mean during the event. The peak intensity of the wind speed is largest in the fjord station and smallest in ERA-Interim (Fig. 4). The time between the initial increase in wind speed and the return to low wind speed is about $20-30 \mathrm{~h}$ in all three datasets. Wind speeds above $10 \mathrm{~m} \mathrm{~s}^{-1}$ are sustained for about $10 \mathrm{~h}$. As the wind speed increases, both temperature and pressure drop. The temperature minimum is reached slightly after the time of maximum wind speed has passed, while the minimum in pressure occurs before the maximum wind speed is reached. Not shown is the relative humidity evolution recorded by the DMI station, but its curve resembles the temperature curve closely with a relative humidity drop of $20 \%$. Also not shown is the DMI station cloud cover evolution. We find that $40 \mathrm{~h}$ before the event the sky has a cloud cover of almost $80 \%$. During the event the sky clears up by more than
$40 \%$. About $10 \mathrm{~h}$ after the event, the cloud cover starts to increase again. The climatological winter mean is a cloud cover of $70 \%$.

A composite of the large-scale wind velocity distribution using ERA-Interim shows strong winds of $\sim 20 \mathrm{~m} \mathrm{~s}^{-1}$ where the flow converges inside the Ammassalik valley (note that ERA-Interim records the maximum wind speeds not directly at the fjord where the two stations are, Fig. 5). The wind speeds remain large as the flow crosses the coastline and are still $\sim 15 \mathrm{~m} \mathrm{~s}^{-1}$ over a large part of the Irminger Sea. The corresponding sea level pressure field indicates that the flow is supported by a synoptic-scale geostrophic flow associated with a cyclone located between Iceland and east Greenland (Fig. 5). Also shown is the ERA-Interim boundary layer height, which is defined as the level where the Richardson number reaches the critical value $\mathrm{Ri}_{\mathrm{cr}}=0.25$ (ECMWF 2010). The DWE and associated cyclone are associated with a significant thickening of the boundary layer over the ocean and over Iceland. The boundary layer height is a diagnostic for the impact that the air-sea interaction is having on the lower troposphere, and 

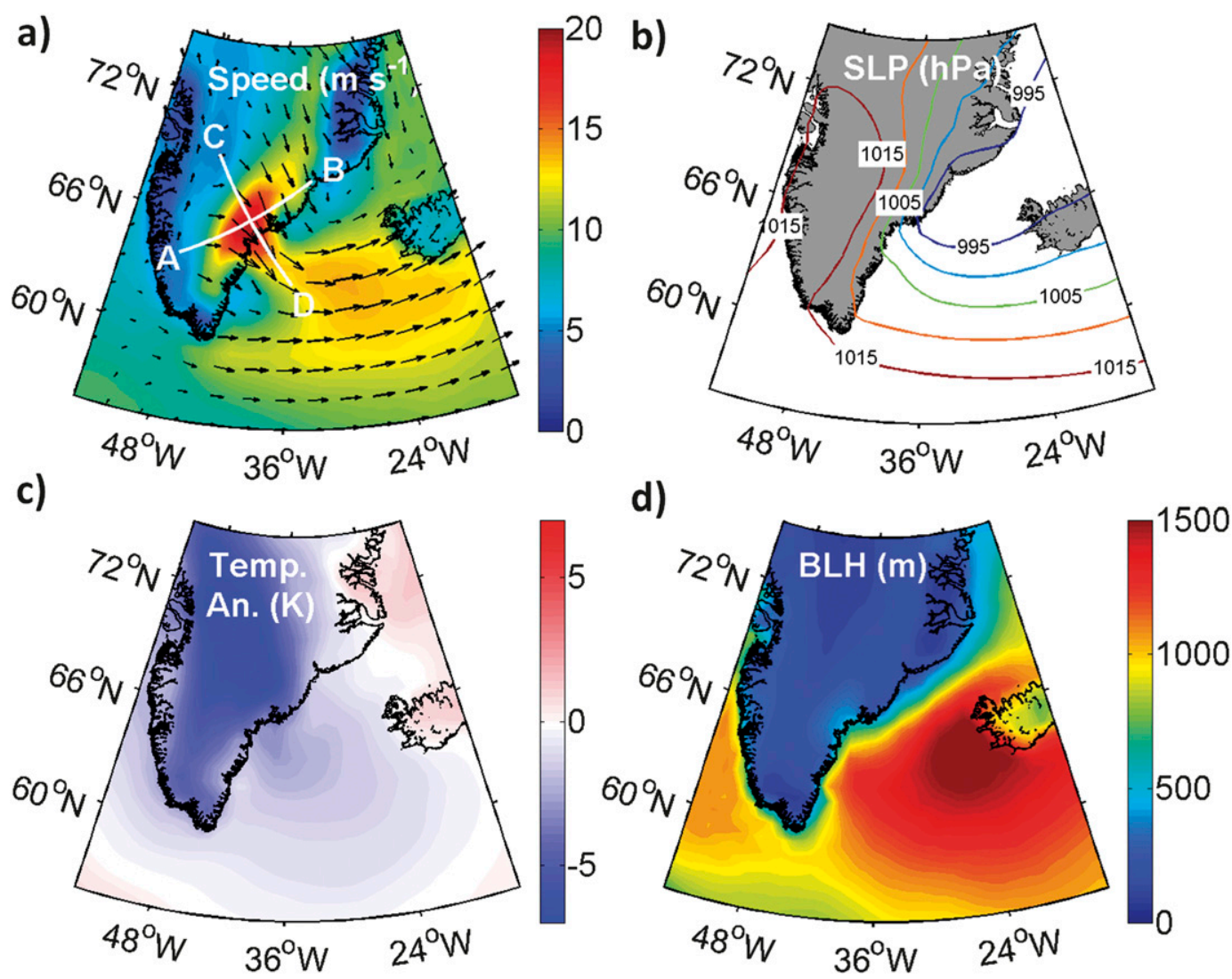

FIG. 5. Composite of the ERA-Interim (a) wind speed, (b) sea level pressure, (c) temperature anomaly, and (d) boundary layer height during DWEs. The temperature anomaly is the difference of the composite of wintertime (November-April) events to the winter climatology. The lines in the wind speed composite mark the sections shown in Fig. 6.

a deep boundary layer can indicate a large heat flux from the ocean to the atmosphere. The 2-m air temperature field (Fig. 5) reveals that the air over large parts of the Greenland ice sheet and especially in the region from where the winds originate is significantly colder during wintertime DWEs compared to the winter climatology. To ensure that these results are not subjective to the specific definition of the DWE, we built these composites in ERA-Interim with slightly different definitions and with DWEs obtained with the DMI station or the fjord station. In each case we found that the composites do not change qualitatively.

Vertical sections from ERA-Interim across and along the composite flow (refer to Fig. 5 for section location) reveal that it consists of a broad jet with speeds of up to $25 \mathrm{~m} \mathrm{~s}^{-1}$, a width of approximately $300 \mathrm{~km}$, and a height of about $2500 \mathrm{~m}$ (Fig. 6). The jet follows the topography closely as it flows downhill and spills over the ocean. The potential temperature profiles indicate that the air is strongly stratified and that there is a large temperature gradient between the air over the ocean and over the ice sheet. Also, the along-section specific humidity shows that the air over the ice sheet is much drier. The temperature anomaly sections reveal that the air over the ice sheet is more than $10^{\circ} \mathrm{C}$ colder during wintertime DWEs compared with the winter climatology. The relative humidity sections confirm that the jet carries air that is largely undersaturated with respect to water vapor. As the air passes over the ocean, its temperature and specific humidity content increase (Fig. 6).

\section{b. Dynamics}

To quantify the forcing of the flow we set up the momentum budget along a linearized composite streamline section obtained from the ERA-Interim 10-m surface winds during DWEs (Fig. 7). The streamline section includes the location of the maximum wind speed in ERA-Interim. We find that it adequately represents surface winds of different events and coincides with the direction of the downslope topographic gradient. Using the hydrostatic approximation (Mahrt 1982), the momentum equation along this section in the downslope 

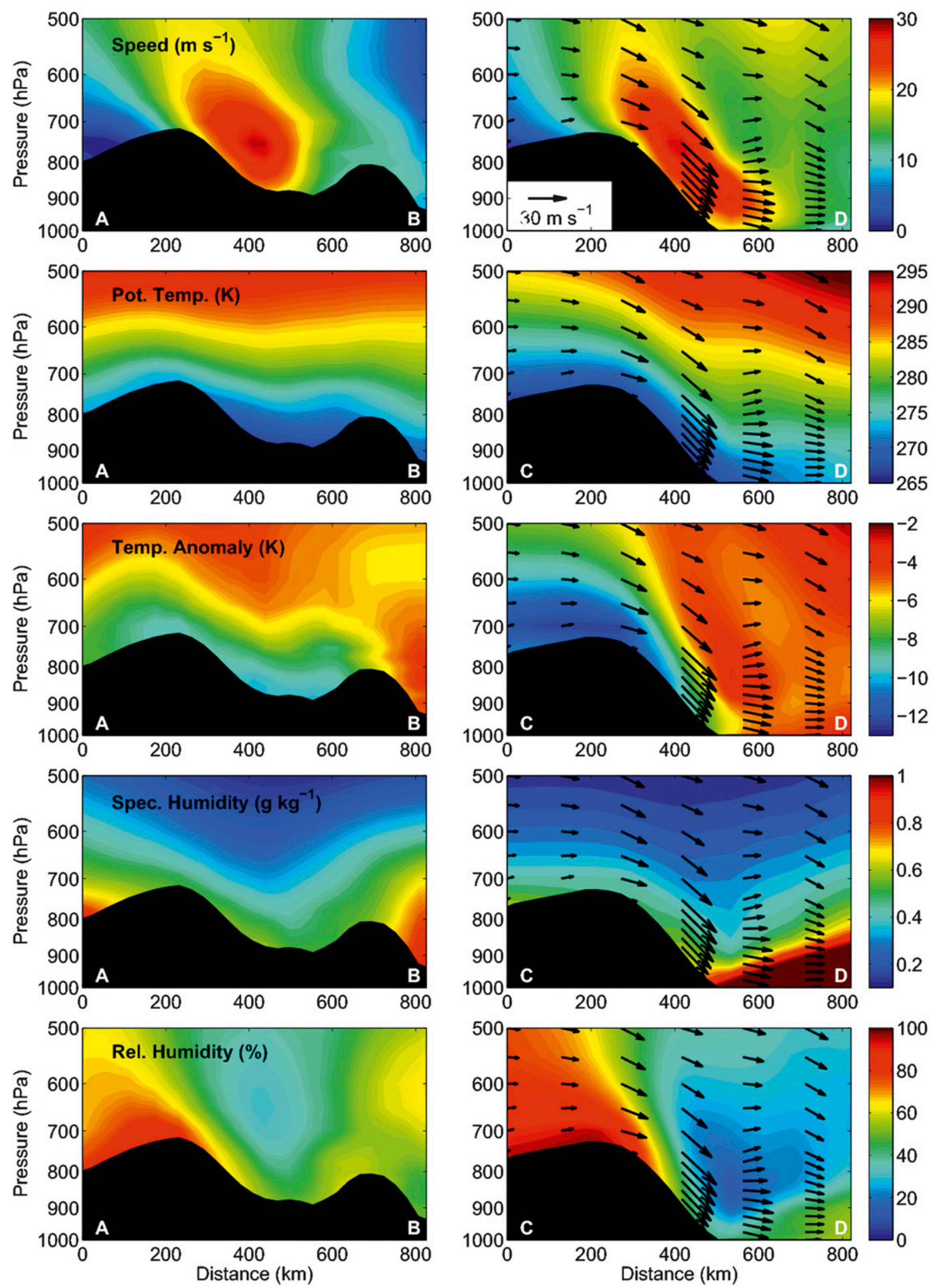

FIG. 6. (left) Cross sections and (right) along sections through the flow from ERA-Interim. The section end points $\mathrm{AB}$ and $\mathrm{CD}$ are shown in Fig. 5a. The winds follow the topography closely. They are dry and cold but become moist and warmer when they cross the coastline. 

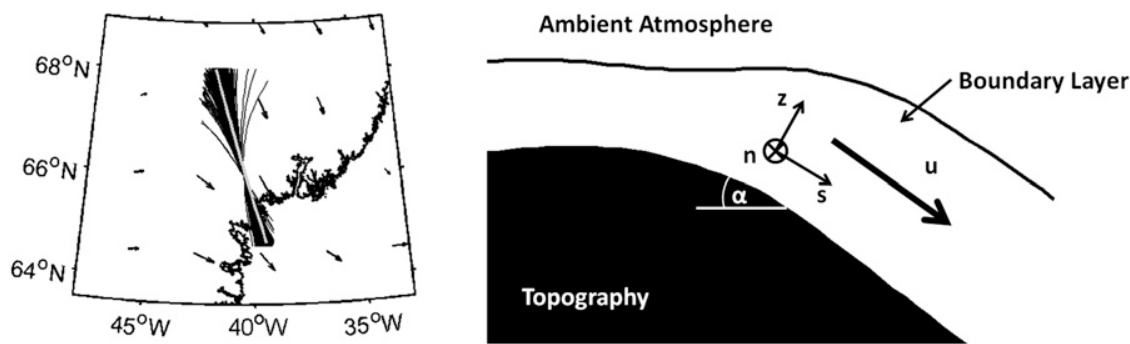

FIG. 7. (left) Streamlines of the 10-m surface winds during DWEs in ERA-Interim; the gray line represents the linearized mean on which the momentum analysis is based on. (right) Profile of the flow in the coordinate system used in the momentum analysis.

direction $s$ can be written as (Van den Broeke et al. 2002; Van den Broeke and Van Lipzig 2003; van Angelen et al. 2011)

$$
\begin{aligned}
& \frac{\partial u}{\partial t}+u \frac{\partial u}{\partial s}+v \frac{\partial u}{\partial n}+w \frac{\partial u}{\partial z}-f v+\frac{\partial \overline{u w}}{\partial z} \\
&=-\frac{1}{\rho_{0}} \frac{\partial p_{S}}{\partial s}-\frac{g}{\theta_{0}} \frac{\partial \hat{\theta}}{\partial s}+\frac{g}{\theta_{0}} \theta \sin (\alpha) \quad \text { and } \\
& \frac{\partial u}{\partial t}+F_{\mathrm{NL}}-F_{C}-F_{R}=F_{S}+F_{T}+F_{G} .
\end{aligned}
$$

Here $z$ is the vertical coordinate perpendicular to the slope (positive upward), $w$ is the vertical velocity, $u$ the downslope velocity, and $v$ the velocity in the cross-slope direction $n ; t$ is time, $\theta_{0}$ is the ambient potential temperature, $\theta$ the temperature deficit, $\rho_{0}$ is density, $p_{S}$ is the superimposed synoptic pressure, $f$ the Coriolis parameter, $g$ gravity, and $\alpha$ is the positive angle of the slope with respect to the horizontal (Fig. 7). We define the temperature deficit as the temperature difference between the boundary layer temperature and that of the ambient atmosphere at the same height (Fig. 8). A positive temperature deficit means that the boundary layer temperature is colder than that of the ambient atmosphere. The term $\hat{\theta}(z)$ is the vertically integrated temperature deficit from $z$ to some arbitrary height $z_{t}$, chosen well above the boundary layer, where the temperature deficit vanishes:

$$
\hat{\theta}(z)=\int_{z}^{z_{t}} \theta d z
$$

On the lhs of Eq. (2) are the local acceleration $\partial u / \partial t$, nonlinear advection $F_{\mathrm{NL}}$, the Coriolis force $F_{C}$, and friction $F_{R}$. We call these forces "passive" since they only exist in the presence of atmospheric motion (van Angelen et al. 2011). The forcing $F_{R}$ includes friction and small-scale processes that are parameterized in the underlying model. On the rhs of Eq. (2) are the active forces that drive the flow. These include the synoptic pressure gradient force $F_{S}$, the thermal force $F_{T}$, and the gravitational force $F_{G}$. Both the thermal force and gravitational force are driven by gravitation. The gravitational acceleration arises because of the presence of the potential temperature deficit over sloping topography, whereas the thermal acceleration is due to inhomogeneities of the temperature deficit along the direction of the flow. It is also responsible for the sea breeze circulation and exists even when the slope is absent, as it only acts upon the horizontal gradient of the temperature deficit. An increase (decrease) in the potential temperature deficit implies a local deceleration (acceleration) of the surface flow.

The synoptic pressure gradient acceleration is defined such that the large-scale flow at some level far above the boundary layer $\left(u_{\mathrm{lsc}}, v_{\mathrm{lsc}}\right)$ is geostrophic: $-f v_{\mathrm{lsc}}=$ $-\rho_{0}^{-1} \partial p_{S} / \partial s$ and $f u_{\mathrm{lsc}}=-\rho_{0}^{-1} \partial p_{S} / \partial n$. For its computation we assume that this flow is in thermal wind balance with the ambient potential temperature $\theta_{0}$ (Van den Broeke et al. 2002; van Angelen et al. 2011):

$$
\begin{aligned}
& \frac{\partial u_{\mathrm{lsc}}}{\partial \ln p}=\frac{R_{g}}{f}\left(\frac{p}{p_{0}}\right)^{R_{g} / c_{p}} \frac{\partial \theta_{0}}{\partial n} \quad \text { and } \\
& \frac{\partial v_{\mathrm{lsc}}}{\partial \ln p}=-\frac{R_{g}}{f}\left(\frac{p}{p_{0}}\right)^{R_{g} / c_{p}} \frac{\partial \theta_{0}}{\partial s},
\end{aligned}
$$

where $R_{g}$ is the gas constant and $c_{p}$ the heat capacity at constant pressure. The computation of the large-scale geostrophic flow includes errors from the determination of the ambient potential temperature, which is found by linearly interpolating the potential temperature profile above some height $z_{t}$ downward to the surface. We carefully investigated the potential temperature profile along the section to make sure that the chosen level $z_{t}$ $2000 \mathrm{~m}$ above the topography is reasonable. Small changes of this level affected the results only marginally. 
a)

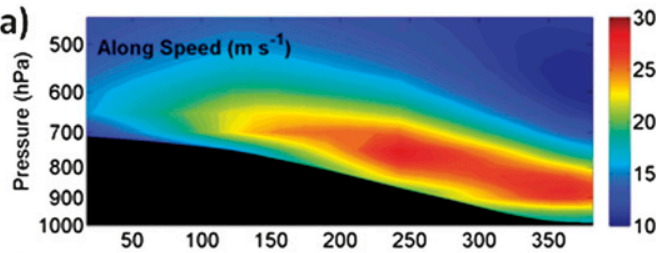

c)

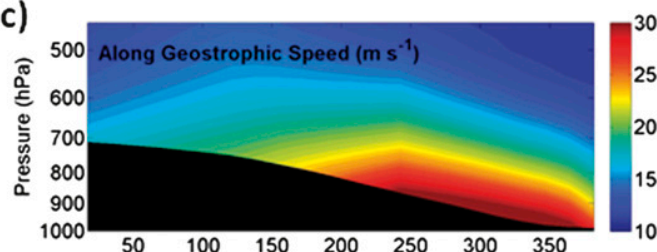

e)

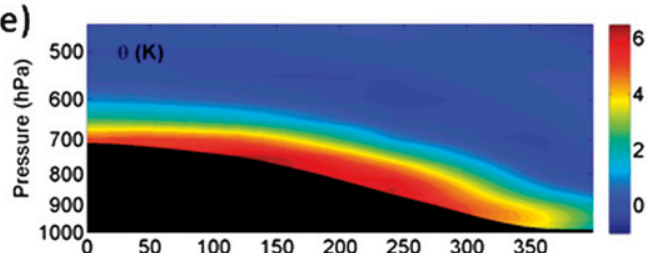

g)

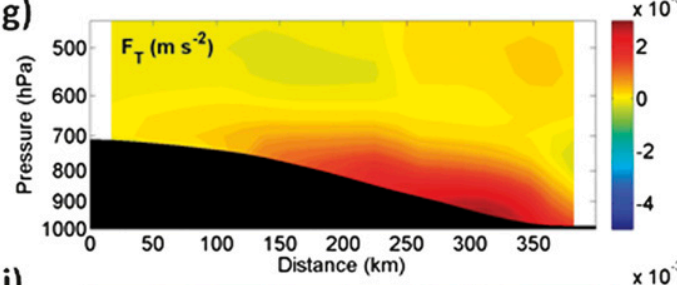

i)

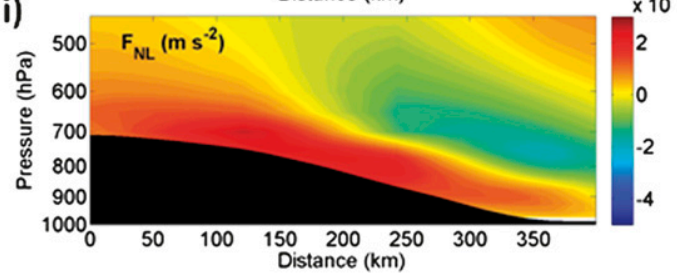

b)

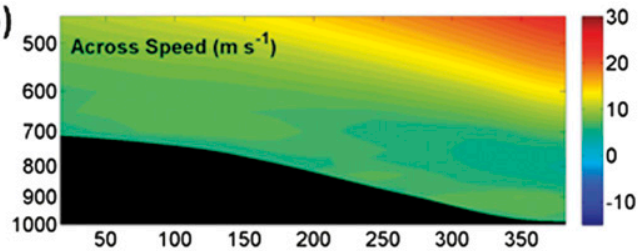

d)

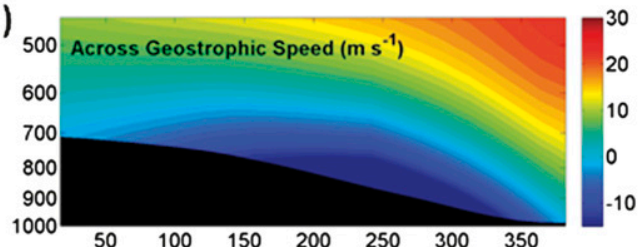

f)

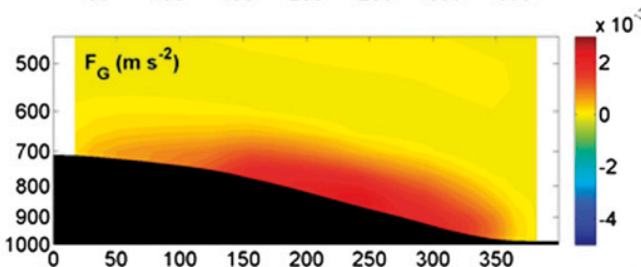

h)

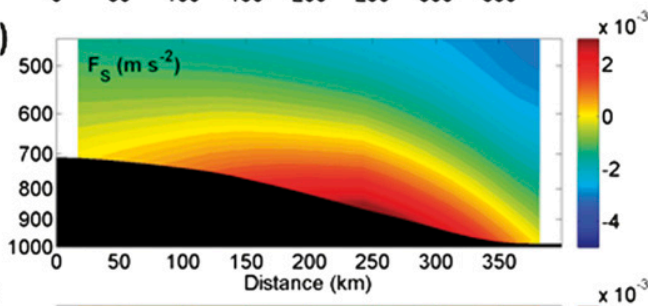

j)

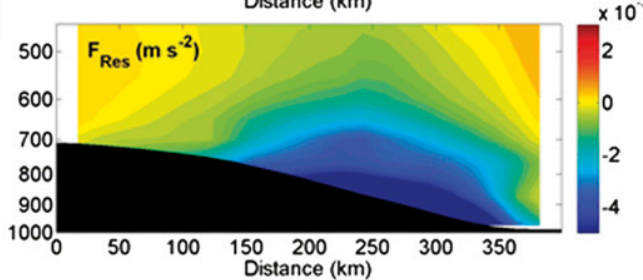

FIG. 8. Composite analysis of the momentum balance during DWEs in ERA-Interim along the section shown in Fig. 7. (a)-(d) Composite of the observed and calculated large-scale geostrophic flow along and across the section. (e) The temperature deficit of the boundary layer with respect to the ambient atmosphere; a positive temperature perturbation means the air is colder than that of the ambient atmosphere. (f)-(h) The gravitational force, thermal force, and synoptic pressure gradient force. (i),(j) The nonlinear advection and the residual.

We compute the synoptic pressure gradient and the associated large-scale geostrophic flow for each DWE, take the composite, and compare it to the observed flow (Fig. 8). Near the surface the observed cross-slope flow is much weaker than what would be predicted from the thermal wind balance with the ambient potential temperature. This could be due to friction and blocking of the cross-slope flow by the mountains surrounding the valley in Ammassalik. In the along-slope direction the observed flow is also likely decelerated by friction close to the surface. Inside the region of the potential temperature deficit it is stronger than the large-scale geostrophic flow and thus must be accelerated by one or several of the forces in the momentum balance [Eq. (2)].
We compute the three active forces, the local acceleration, the Coriolis force, and the nonlinear force individually for each DWE in ERA-Interim and then take the composite (Fig. 8). We cannot close the momentum budget in ERA-Interim since we cannot estimate the small-scale turbulence that is parameterized in the underlying model, so the residual force must be inferred from the other terms. We find that the three active forces are of comparable magnitude: 1) $F_{G}$ is strongest where the temperature deficit is largest and the slope is steepest, which occurs over the central part of the slope;2) $F_{T}$ is the largest force near the coast but is also important over the slope; and 3) $F_{S}$ is large near the surface and becomes negative at height. The local acceleration is more than 
one order of magnitude smaller than the other terms, which could be due to the coarse temporal resolution of the ERA-Interim output. Evaluating the local acceleration with the station data, we still find that it is one order of magnitude smaller than the other terms. The forcing $F_{\mathrm{NL}}$ is partly balancing the three active forces, and we infer that there must still be a considerable residual force. The residual force (friction) impedes the flow and is especially pronounced near the surface. It is also important above the surface where the wind speed is large and the unresolved turbulent processes can have a significant impact on the flow (Van den Broeke et al. 2002; Outten et al. 2009).

In addition, there could be momentum transport in internal gravity waves (Gill 1982; Durran 1990). Indeed, Doyle et al. (2005) observed large amplitude mountain wave breaking in Ammassalik during a DWE on 29 January 1997 that was also obtained with ERA-Interim. During this same event we observe downward trending potential temperature isopleths from the interior toward the sea in ERA-Interim (not shown), indicating a katabatic condition and evanescent mountain waves, which suggests that ERA-Interim does not resolve the complete wave dynamics. Even so, based on the agreement we find between ERA-Interim and the station data (section 4) and that our results are in line with previous studies (e.g., Klein and Heinemann 2002; Heinemann and Klein 2002), we believe that our results give a plausible estimate of the forcing of the flow and are qualitatively valid.

\section{c. Impacts}

\section{1) DownStReAm BUOYANCY FLUX}

The buoyancy loss at the surface of the ocean that occurs during intense winter storms is a major driver of deep and intermediate ocean convection (Marshall and Schott 1999; Sathiyamoorthy and Moore 2002). DWEs advect cold, dry air over the ocean and, as such, are likely associated with large heat and ocean buoyancy fluxes. To examine their impact we investigate the buoyancy flux associated with these events.

The buoyancy flux $B$ is the sum of a thermal and a saline contribution, where the thermal contribution includes the radiative and turbulent heat fluxes $Q$, and the saline contribution is tied to changes in surface water density owing to precipitation or evaporation (Gill 1982):

$$
\begin{aligned}
B & =\frac{g \alpha}{\rho_{0} C_{p}} Q+\frac{\beta S C_{p}}{\alpha}(P-E) \quad \text { and } \\
Q & =\left(Q_{S}+Q_{L}+Q_{\mathrm{SW}}+Q_{\mathrm{LW}}\right) .
\end{aligned}
$$

Here $\alpha(\beta)$ are the thermal (haline) expansion coefficients for seawater, $C_{p}$ is its specific heat, $g$ the gravitational acceleration, $\rho_{0}$ a reference density, and $P$ and $E$ are precipitation and evaporation. Term $Q_{S}$ is the sensible heat flux, $Q_{L}$ the latent heat flux, $Q_{\mathrm{Sw}}\left(Q_{\mathrm{LW}}\right)$ is the heat flux due to the net shortwave (longwave) radiation. All of these variables are obtained from ERA-Interim and used to evaluate the buoyancy flux associated with DWEs. A sign convention is used such that a positive heat flux corresponds to a heat gain of the ocean and a negative buoyancy flux corresponds to a densification of the water at the ocean surface.

Since deep and intermediate ocean convection is known to be intermittent and tied to the occurrence of intense atmospheric forcing, we start by investigating the turbulent fluxes, the total heat flux, and the buoyancy flux for one of the stronger events that took place on 28 December 2004. During this event ERA-Interim shows maximum surface wind speeds of $25.9 \mathrm{~m} \mathrm{~s}^{-1}$ and a total heat flux up to $-1000 \mathrm{~W} \mathrm{~m}^{-2}$ over a part of the Irminger Sea (Fig. 9). This is comparable to other strong wind events in this region that are known to force convection in the Irminger Sea (e.g., Våge et al. 2009; Vage 2010; Pickart et al. 2003a). While this is one of the stronger events, its overall appearance, especially the tail that extends to south of Iceland, is representative of many events.

A composite of the heat and buoyancy fluxes during the wintertime (November-April) DWEs shows a similar structure but with reduced amplitude (Fig. 9). We find that the majority of the buoyancy loss over the Irminger Sea during wind the events is caused by the turbulent heat fluxes. Near the coast, however, there is a small negative contribution to the buoyancy flux from the outgoing radiation and a small positive contribution from the incoming solar radiation. While the sensible heat flux is strongest close to the coast and then decreases relatively fast over the Irminger Sea, the latent heat flux remains high over a significant area.

Mean turbulent heat fluxes during DWEs are about $-400 \mathrm{~W} \mathrm{~m}^{-2}$, which is the same order of magnitude as the turbulent heat fluxes that occur during tip jet events (Våge et al. 2009). However, we stress that the region of maximum heat loss during tip jets is shifted southward compared to that during DWEs, as is the cyclone that is forcing DWEs. We note that the two types of wind events can potentially be forced by the same synoptic system. Indeed, if we assume that tip jets occur before DWEs and allowing for a time lag of 2 days, we find that $31 \%$ of DWEs are preceded by a tip jet [using the tip jet climatology from Våge et al. (2009)]. Here, we have estimated the 2-day time lag to be an average travel time of the cyclone from its tip-jet-forcing position to its 

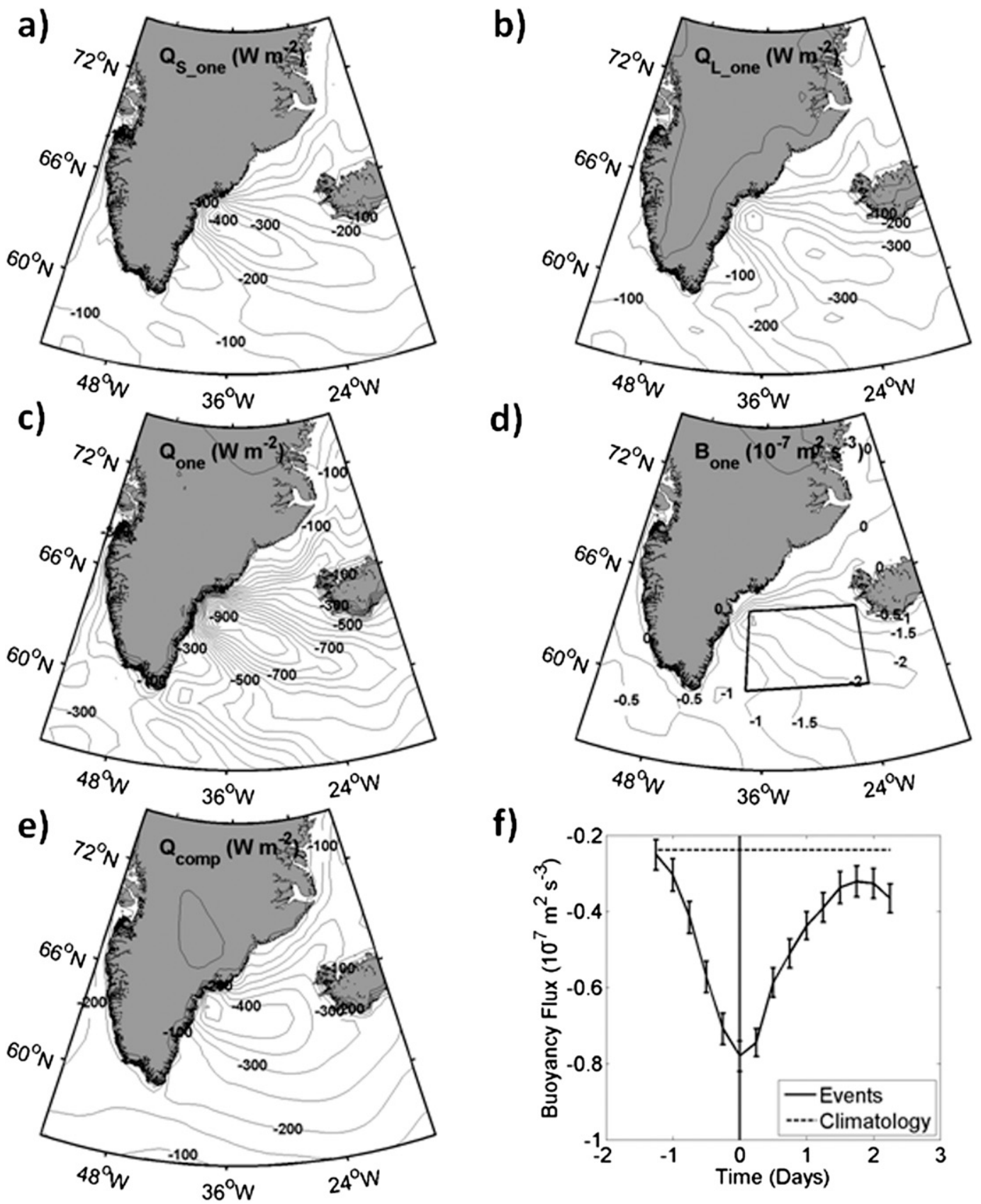

f)

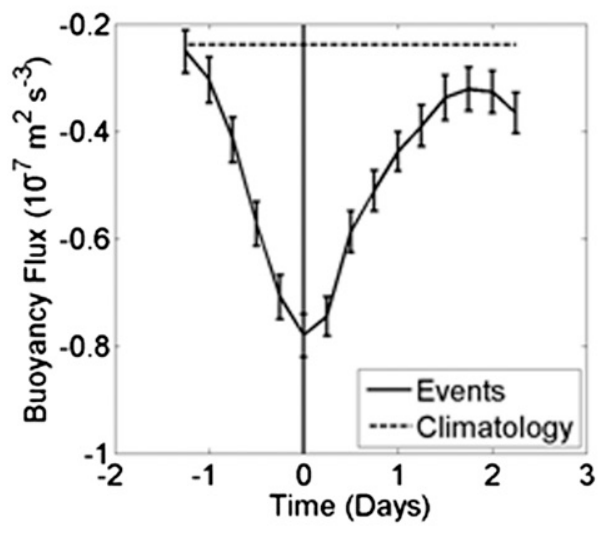

FIG. 9. Snapshot of the (a) sensible, (b) latent, and (c) total heat flux from ERA-Interim for an individual DWE that occurred on 28 Dec 2004. The sensible and latent heat flux are the major contributors to the (d) buoyancy loss during this wind event. (e) Composite of the total heat flux of the wintertime DWEs in ERA-Interim. (f) Composite of the ERA-Interim buoyancy flux evolution associated with all wintertime DWEs over the Irminger Sea box shown in (d). Zero days indicates the time of the maximum wind speed. The climatological mean (November-April) is shown for reference. The duration of the buoyancy loss is almost 3 days.

DWE-forcing position based on a composite of the sea level pressure evolution.

To quantify the buoyancy loss associated with DWEs we use the box shown in Fig. 9. It covers a large part of the northern Irminger Sea, extends eastward over the
Reykjanes Ridge, and includes the northernmost part of the Irminger gyre in which convection is known to occur, as well as a part of the Irminger Current that is connected to the gyre (e.g., Våge et al. 2011; Lavender et al. 2000). The area captures a large signal of DWEs but 

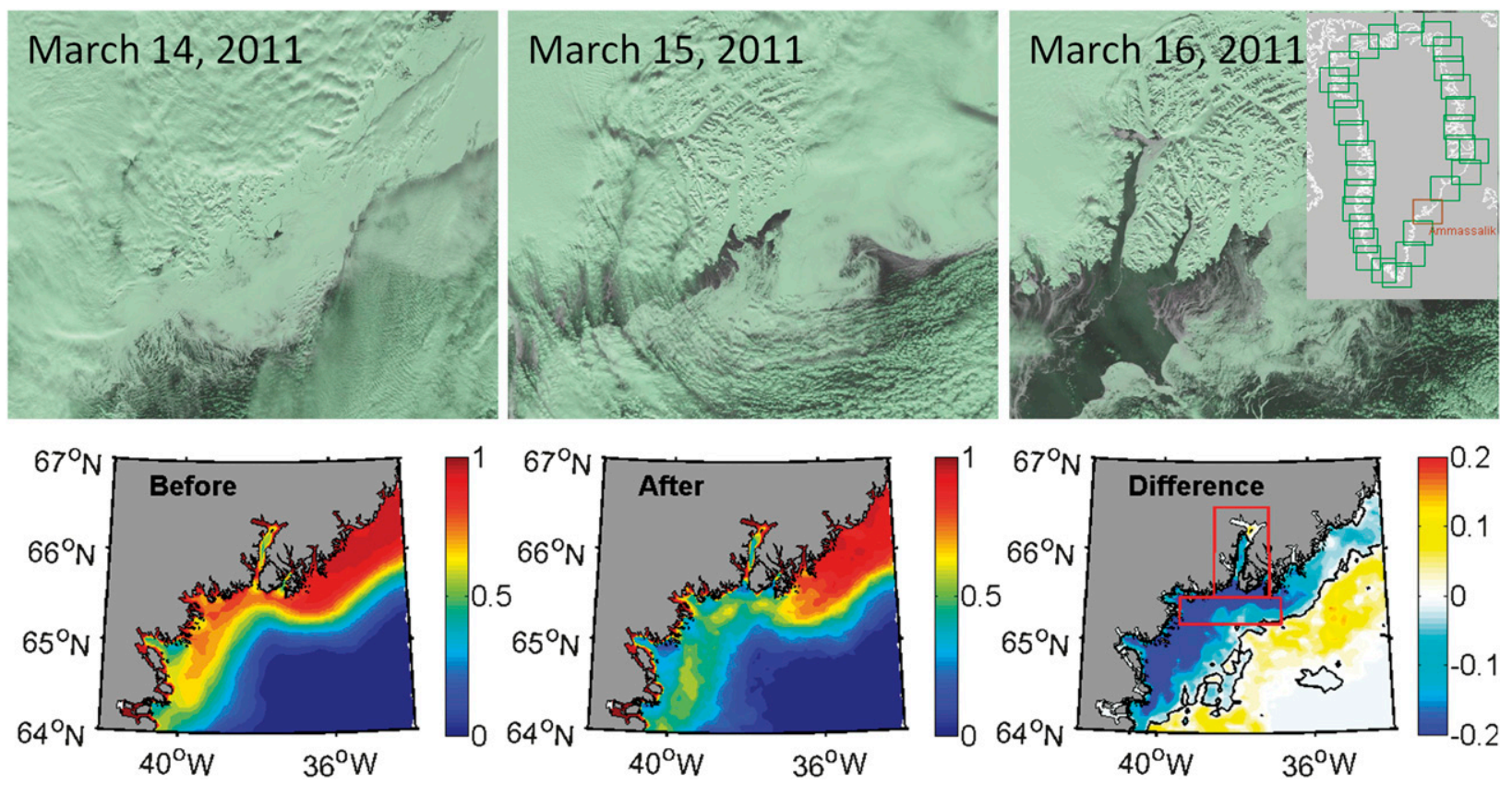

FIG. 10. (top) Satellite images of a specific event in the visible range [Moderate Resolution Imaging Spectroradiometer (MODIS)] show how the ice is advected out of the fjord and away from the coast during the wind event. (bottom) Composite of satellite-derived (AMSR-E) mean sea ice concentration averaged during the week before the event, the day after the event, and the difference. Note the different color bar for the difference.

excludes most of the signal due to tip jets. Within this area, we find that the buoyancy flux associated with a DWE lasts for almost 3 days (Fig. 9). To estimate the buoyancy loss due to all 166 wintertime DWEs, $\mathcal{B}_{\text {DWE}}$, we integrate the buoyancy flux from $30 \mathrm{~h}$ before each event (i.e., the time of maximum wind speed) until $38 \mathrm{~h}$ after each event over the box and sum all the events. We compare it to the total wintertime buoyancy loss over the 32 years over the same area $\mathcal{B}_{\text {Clim }}$.

Our estimates yield

$$
\frac{\mathcal{B}_{\text {DWE }}}{\mathcal{B}_{\text {Clim }}} \approx 19 \%
$$

Thus, summing the contributions from all DWEs, we find that these wind events account for one-fifth of the net buoyancy loss during winter even though they only span $9 \%$ of the time. We note that the buoyancy flux during DWE is due both to the downslope wind and the connected low pressure system.

\section{2) IMPACT ON SEA ICE}

To investigate the impact of DWEs on the regional sea ice cover we combine an inspection of MODIS visible images and analysis of AMSR-E data. MODIS satellite images (not shown) often indicate that during an individual DWE the sea ice is advected away from the coast and the entire fjord-including the ice mélangeis cleared (e.g., Fig. 10). Since cloud cover renders a thorough analysis using the visible wave band difficult, we use the AMSR-E sea ice concentration product (based on the $89-\mathrm{GHz}$ channel) to determine the wind impact on sea ice. Comparison of the sea ice during individual events shows that the AMSR-E satellite product is in good agreement with the MODIS satellite images.

Further analysis of the AMSR-E sea ice product shows that sea ice is normally present along the southeast Greenland coast between January and May. During these months in the period from 2003 to 2010 (when AMSR-E is operating) we identify 32 DWEs from the fjord station data. The impact of these events on sea ice cover is studied by comparing the mean sea ice distribution averaged during the week before the event with the sea ice distribution from the day after the event (Fig. 10). The comparison clearly shows that during the DWE ice is advected away from the coast. We quantify this reduction by calculating the mean ice concentration before and after the wind event both inside the fjord and in a confined region of the surrounding shelf (regions shown in Fig. 10). On the day after the wind event, the ice concentration inside the fjord is reduced by $29 \%$ while on the shelf it is reduced by $26 \%$. 


\section{Discussion and conclusions}

We have built a composite of downslope wind events (DWEs) and thereby generalized previous case studies of individual events (e.g., Mills and Anderson 2003; Klein and Heinemann 2002; Heinemann and Klein 2002). The identification and description of DWEs is based on three different datasets, including two meteorological stations and the ERA-Interim product. Despite the different characteristics of the datasets, the results agree well. DWEs predominantly occur in winter and manifest themselves as strong winds in Ammassalik, including Sermilik Fjord. A broad jet with peak wind speeds above $25 \mathrm{~m} \mathrm{~s}^{-1}$ and a height of $2500 \mathrm{~m}$ (in ERA-Interim) closely follows the downhill topography and converges inside the Ammassalik valley. At the surface close to Sermilik Fjord, the fjord station records the fastest wind with speeds above $20 \mathrm{~m} \mathrm{~s}^{-1}$. This could be an indication of the importance of the local topographic setting not being fully resolved by ERA-Interim.

We do see evidence for a pronounced gravitational and thermal acceleration of the flow in all three datasets. There is a distinct surface air temperature drop inside Sermilik Fjord, indicating that cold (i.e., dense) air has been advected downslope, as is typical for katabatic flows. Also, vertical profiles from ERA-Interim show that the air over the ice sheet is strongly stratified and generally colder during the wind events compared to the winter climatology, and the large temperature deficit over the ice sheet results both in a strong thermal and gravitational acceleration. Another indication of the heat loss of the surface air and stabilization of the boundary layer is the decrease in cloud cover during the DWE recorded at the DMI station. The importance of gravitational and thermal acceleration is further confirmed by analysis of the momentum budget for a section along the downslope flow in ERA-Interim. Over the central part of the slope, the gravitational acceleration is the dominant forcing term, but as the flow approaches the coast the thermal acceleration becomes more important.

All three datasets further show evidence of a synoptic pressure gradient force. Both meteorological stations record a drop in pressure prior to the wind event, and ERA-Interim indicates a synoptic-scale cyclone between Iceland and Greenland such that the large-scale geostrophic flow is approximately in the same direction as the downhill topographic gradient. Apart from close to the surface, but inside the potential temperature deficit layer, we find that the observed along-slope flow is stronger compared to the large-scale geostrophic flow, which is an indication for the effect that the thermal and gravitational acceleration have on the flow as well as a synoptic-scale pressure gradient acceleration that is unbalanced by the Coriolis force inside the Ammassalik valley.

Previous studies (e.g., Durran 1990) suggest that downslope wind storms can be forced by mountain waves or a combination of katabatic flows and mountain waves (Poulos et al. 2000, 2007). Gravity waves were also observed during a katabatic wind event in west Greenland (Heinemann 1999), and Doyle et al. (2005) observed large-amplitude wave breaking during an individual DWE in Ammassalik. While ERA-Interim does resolve waves, these are mostly evanescent [both in the composite and in the event studied by Doyle et al. (2005)], which suggests that ERA-Interim only partially resolves the wave dynamics of DWEs.

During a DWE cold, dry air that is found above the ice sheet spills over the ocean, which results in a significant deepening of the boundary layer of the atmosphere and in large buoyancy losses from the surface ocean. We estimate that the buoyancy loss due to the wintertime DWEs and the associated cyclone is one-fifth of the total wintertime buoyancy loss over a large part of the Irminger Sea. Mean heat fluxes during a DWE $\left(\sim 400 \mathrm{~W} \mathrm{~m}^{-2}\right)$ are comparable to those occurring during tip jet events, but they cover a different part of the Irminger Sea farther north (Pickart et al. 2003a; Våge et al. 2009). Peak heat fluxes can amount to $-1000 \mathrm{~W} \mathrm{~m}^{-2}$. For comparison with other convection regions Moore et al. (2002) find peak fluxes of about $-500 \mathrm{~W} \mathrm{~m}^{-2}$ in the Weddell Polynya in Antarctica. Petersen and Renfrew (2009) use direct observations to calculate heat fluxes over Denmark Strait and the Irminger Sea during high wind speed conditions. They estimate the total heat flux to amount to $-600 \mathrm{~W} \mathrm{~m}^{-2}$, which is still less than what we find during an extreme DWE. Most of the buoyancy loss occurs over the Irminger Current, which flows around the Irminger gyre where deep convection occurs (e.g., Våge et al. 2011; Pickart et al. 2003b; de Jong et al. 2012). Thus, DWEs have a large potential for preconditioning or driving convection.

Finally, we find that DWEs significantly reduce coastal sea ice cover. We estimate a $29 \%$ reduction of sea ice inside Sermilik Fjord and a $26 \%$ reduction on the surrounding shelf compared to the mean sea ice concentration the week before the event. The advection of sea ice offshore likely results in a faster melting of sea ice owing to warmer water in the interior Irminger Sea (Sutherland et al.2013) and, thus, to a local freshening of the Irminger Sea. Considering that DWEs could occur all along the east Greenland coast, their combined offshore advection of sea ice could be substantial (Dodd et al. 2012). It is possible that this offshore advection of sea ice could result in a significant freshwater transport into the interior. Assessing its magnitude is not trivial 
because of the lack of ice thickness data but should be the focus of future studies.

In addition, the removal of sea ice affects the energy balance of the surface water since sea ice has insulating properties and influences the amount of sunlight reaching the water surface. The removal of ice from Sermilik Fjord may explain why the ice cover in Sermilik Fjord is often mobile, even in winter. Further, it has been found that a dense ice cover (sea ice and icebergs) near outlet glaciers is important for glacier stability (Amundson et al. 2010) and that reductions in the ice cover correlate with glacier retreat (Howat et al. 2010; Walter et al. 2012). Thus, DWEs in Ammassalik and Sermilik Fjord could have an impact on the stability of Helheim Glacier.

Acknowledgments. This study was supported by grants of the National Science Foundation (OCE-0751554 and OCE-1130008) as well as the Natural Sciences and Engineering Research Council of Canada. We thank the DMI and the University of Copenhagen for providing the data from their meteorological stations, ECMWF for providing the reanalysis data, the NSIDC for providing the AMSR-E data, and the University of Hamburg for processing the sea ice concentration data for improving the resolution. QuikSCAT data are produced by Remote Sensing Systems and sponsored by the NASA Ocean Vector Winds Science Team. We also thank three anonymous reviewers who have considerably improved the manuscript.

\section{REFERENCES}

Amundson, J. M., M. Fahnestock, M. Truffer, J. Brown, M. Lüthi, and R. Motyka, 2010: Ice mélange dynamics and implications for terminus stability, Jakobshavn Isbræ, Greenland. J. Geophys. Res., 115, F01005, doi:10.1029/2009JF001405.

Born, E. W., and J. B. Boecher, 2000: The Ecology of Greenland. Atuakkiorfik Education, $429 \mathrm{pp}$.

Bromwich, D. H., and D. D. Kurtz, 1984: Katabatic wind forcing of the Terra Nova Bay polynya. J. Geophys. Res., 89 (C3), 35613572.

_, Y. Du, and K. M. Hines, 1996: Wintertime surface winds over the Greenland ice sheet. Mon. Wea. Rev., 124, 1941-1947.

Cappelen, J., 2011: DMI monthly climate data collection 17682010, Denmark, the Faroe Islands and Greenland. Danish Meteorological Institute Tech. Rep. 11-05, 54 pp.

Carstensen, L. S., and B. V. Jorgensen, 2010: Weather and climate data from Greenland 1958-2009. Danish Meteorological Institute Tech. Rep. 10-08, 22 pp.

Cavalieri, D., T. Markus, and J. Comiso, 2004: AMSR-E/Aqua daily L3 $12.5 \mathrm{~km}$ brightness temperature, sea ice concentration, and snow depth polar grids, version 2. National Snow and Ice Data Center, Boulder, CO, digital media. [Available online at http://nsidc.org/data/ae_si12.html.]

Dee, D. P., and Coauthors, 2011: The ERA-Interim reanalysis: Configuration and performance of the data assimilation system. Quart. J. Roy. Meteor. Soc., 59, 141-161. de Jong, M. F., H. M. van Aken, K. Våge, and R. S. Pickart, 2012: Convective mixing in the central Irminger Sea: 2002-2010. Deep-Sea Res. I, 63, 36-51.

Dodd, P. A., B. Rabe, E. Hansen, E. Falck, A. Mackensen, E. Rohling, C. Stedmon, and S. Kristiansen, 2012: The freshwater composition of the Fram Strait outflow derived from a decade of tracer measurements. J. Geophys. Res., 117, C11005, doi:10.1029/2012JC008011.

Doyle, J. D., and M. A. Shapiro, 1999: Flow response to large-scale topography: The Greenland tip jet. Tellus, 51, 728-748.

,-- Q. Jiang, and D. L. Bartels, 2005: Large-amplitude mountain wave breaking over Greenland. J. Atmos. Sci., 62, 3106-3126.

Durran, D. R., 1990: Mountain waves and downslope winds. Atmospheric Processes over Complex Terrain, Meteor. Monogr., No. 45, Amer. Meteor. Soc., 59-83.

ECMWF, 2010: IFS documentation-Cy31r1. Part IV: Physical processes. ECMWF Rep. 155 pp.

Gallée, H., 1997: Air-sea interactions over Terra Nova Bay during winter: Simulation with a coupled atmosphere-polynya model. J. Geophys. Res., 102 (D12), 13 835-13849.

Gill, A. E., 1982: Atmosphere-Ocean Dynamics. Academic Press, $662 \mathrm{pp}$.

Harden, B. E., and I. A. Renfrew, 2012: On the spatial distribution of high winds off southeast Greenland. Geophys. Res. Lett., 39, L14806, doi:10.1029/2012GL052245.

,-- , and G. N. Petersen, 2011: A climatology of wintertime barrier winds off southeast Greenland. J. Climate, 24, 4701-4717.

Heinemann, G., 1999: The KABEG`97 field experiment: An aircraftbased study of katabatic wind dynamics over the Greenland ice sheet. Bound.-Layer Meteor., 93, 75-116.

_ 2003: Forcing and feedback mechanisms between the katabatic wind and sea ice in the coastal areas of polar ice sheets. Global Atmos. Ocean Syst., 9, 169-201.

—_, and T. Klein, 2002: Modelling and observations of the katabatic flow dynamics over Greenland. Tellus, 54A, 542-554.

Hennessey, J. P., 1977: Some aspects of wind power statistics. J. Appl. Meteor. Climatol., 16, 119-128.

Howat, I. M., J. E. Box, Y. Ahn, A. Herrington, and E. M. McFadden, 2010: Seasonal variability in the dynamics of marine-terminating outlet glaciers in Greenland. J. Glaciol., 56, 601-613.

Jungclaus, J. H., H. Haak, M. Latif, and U. Mikolajewicz, 2005: Arctic-North Atlantic interactions and multidecadal variability of the meridional overturning circulation. J. Climate, 18, 4013-4031.

Klein, T., and G. Heinemann, 2002: Interaction of katabatic winds and mesocyclones near the eastern coast of Greenland. Meteor. Appl., 9, 407-422.

Lavender, K. L., R. E. Davis, and B. Owens, 2000: Mid-depth recirculation observed in the interior Labrador and Irminger Seas by direct velocity measurements. Nature, 109, 66-69.

Loewe, F., 1972: The land of storms. Weather, 27, 110-121.

Mahrt, L., 1982: Momentum balance of gravity flows. J. Atmos. Sci., 39, 2701-2711.

Marshall, J., and F. Schott, 1999: Open-ocean convection: Observations, theory, and models. Rev. Geophys., 37, 1-64.

Mernild, S. H., B. U. Hansen, B. H. Jakobsen, and B. Hasholt, 2008: Climatic conditions at the Mittivakkat Glacier catchment (1994-2006), Ammassalik Island, SE Greenland, and in a 109-year perspective (1898-2006). Geogr. Tidsskr., 108, 51-72.

Mills, B. J., and M. R. Anderson, 2003: Monitoring a piteraq storm system using DMSP imagery and Quikscat wind data. Preprints, 12th Conf. on Satellite Meteorology and Oceanography, 
Long Beach, CA, Amer. Meteor. Soc., JP2.8. [Available online at https://ams.confex.com/ams/annual2003/webprogram/ Paper56928.html.]

Moore, G. W. K., 2003: Gale force winds over the Irminger Sea to the east of Cape Farewell, Greenland. Geophys. Res. Lett., 30, 1894, doi:10.1029/2003GL018012.

- 2012: A new look at Greenland flow distortion and its impact on barrier flow, tip jets and coastal oceanography. Geophys. Res. Lett., 39, L22806, doi:10.1029/2012GL054017.

—, and I. A. Renfrew, 2005: Tip jets and barrier winds: A QuikSCAT climatology of high wind speed events around Greenland. J. Climate, 18, 3713-3725.

$\longrightarrow$, K. Alverson, and I. A. Renfrew, 2002: A reconstruction of the air-sea interaction associated with the Weddell Polynya. J. Phys. Oceanogr., 32, 1685-1698.

— I. A. Renfrew, and R. S. Pickart, 2012: Spatial distribution of air-sea heat fluxes over the sub-polar North Atlantic Ocean. Geophys. Res. Lett., 39, L18806, doi:10.1029/2012GL053097.

$\_,-$, and J. J. Cassano, 2013: Greenland plateau jets. Tellus, 65A, 17 468, doi:10.3402/tellusa.v65i0.17468.

Outten, S. D., I. A. Renfrew, and G. N. Petersen, 2009: An easterly tip jet off Cape Farewell, Greenland. II: Simulations and dynamics. Quart. J. Roy. Meteor. Soc., 135, 1934-1949.

Palutikof, J. P., B. B. Brabson, D. H. Lister, and S. T. Adcock, 1999: A review of methods to calculate extreme wind speeds. Meteor. Appl., 6, 119-132.

Parish, T. R., and D. H. Bromwich, 1987: The surface windfield over the Antarctic ice sheets. Nature, 328, 51-54.

— and J. J. Cassano, 2001: Forcing of the wintertime Antarctic boundary layer winds from the NCEP-NCAR global reanalysis. J. Appl. Meteor. Climatol., 40, 810-821.

$\longrightarrow$, and - 2003: The role of katabatic winds on the Antarctic surface wind regime. Mon. Wea. Rev., 131, 317-333.

Pavia, E. G., and J. J. O'Brien, 1986: Weibull statistics of wind speed over the ocean. J. Appl. Meteor. Climatol., 25, 1324-1332.

Petersen, G. N., and I. A. Renfrew, 2009: Aircraft-based observations of air-sea fluxes over Denmark Strait and the Irminger Sea during high wind speed conditions. Quart. J. Roy. Meteor. Soc., 135, 2030-2045.

- — - and G. W. K. Moore, 2009: An overview of barrier winds off southeastern Greenland during the Greenland flow distortion experiment. Quart. J. Roy. Meteor. Soc., 135, 19501967.

Pettré, P., C. Payan, and T. R. Parish, 1993: Interaction of katabatic flow with local thermal effects in a coastal region of Adelie Land, East Antarctica. J. Geophys. Res., 98 (D6), 10429 10440.

Pickart, R. S., M. A. Spall, M. H. Ribergaard, G. W. K. Moore, and R. F. Milliff, 2003a: Deep convection in the Irminger Sea forced by the Greenland tip jet. Nature, 424, 152-156.

—, F. Straneo, and G. W. K. Moore, 2003b: Is Labrador Sea water formed in the Irminger Basin? Deep-Sea Res. I, 50, $23-52$.

Poulos, G. S., J. E. Bossert, T. B. McKee, and R. A. Pielke, 2000: The interaction of katabatic flow and mountain waves. Part I: Observations and idealized simulations. J. Atmos. Sci., 57, 1919-1936.

,,-- , and R. A. Pielke Sr., 2007: The interaction of katabatic flow and mountain waves. Part II: Case study analysis and conceptual model. J. Atmos. Sci., 64, 1857-1879.

Putnins, P., 1970: The Climate of Greenland. Elsevier, 128 pp.

Rasmussen, L., 1989: Greenland winds and satellite imagery. Vejret, 32-37.
Renfrew, I. A., and P. S. Anderson, 2002: The surface climatology of an ordinary katabatic wind regime in Coats Land, Antarctica. Tellus, 54, 463-484.

— , and Coauthors, 2008: The Greenland flow distortion experiment. Bull. Amer. Meteor. Soc., 89, 1307-1324.

—, S. D. Outten, and G. W. K. Moore, 2009a: An easterly tip jet off Cape Farewell, Greenland. I: Aircraft observations. Quart. J. Roy. Meteor. Soc., 135, 1919-1933.

— , G. N. Petersen, D. A. J. Sproson, G. W. K. Moore, H. Adiwidjaja, S. Zhang, and R. North, 2009b: A comparison of aircraft-based surface-layer observations over Denmark Strait and the Irminger Sea with meteorological analyses and QuikSCAT winds. Quart. J. Roy. Meteor. Soc., 135, 2046-2066.

Ricciardulli, L., and F. Wentz, 2011: Reprocessed QuikSCAT (V04) wind vectors with Ku-2011 geophysical model function. Remote Sensing Systems Tech. Rep. 043011, 8 pp.

Sabine, C. L., and Coauthors, 2004: The oceanic sink for anthropogenic $\mathrm{CO}_{2}$. Science, 305, 367-371.

Sathiyamoorthy, S., and G. Moore, 2002: Buoyancy flux at Ocean Weather Station Bravo. J. Phys. Oceanogr., 32, 458-474.

Schwerdtfeger, W., 1984: Weather and Climate of the Antarctic. Elsevier, 261 pp.

Spreen, G., L. Kaleschke, and G. Heygster, 2008: Sea ice remote sensing using AMSR-E 89-GHz channels. J. Geophys. Res., 113, C02S03, doi:10.1029/2005JC003384.

Stouffer, R. J., and Coauthors, 2006: Investigating the causes of the response of the thermohaline circulation to past and future climate changes. J. Climate, 19, 1365-1387.

Sutherland, D. A., F. Straneo, G. B. Stenson, F. J. M. Davidson, M. O. Hammill, and A. Rosing-Asvid, 2013: Atlantic water variability on the SE Greenland continental shelf and its relationship to SST and bathymetry. J. Geophys. Res., doi:10.1029/ 2012JC008354, in press.

Våge, K., 2010: Circulation and convection in the Irminger Sea. Ph.D. dissertation, Massachusetts Institute of Technology/ Woods Hole Oceanographic Institute, 149 pp.

, T. Spengler, H. C. Davies, and R. S. Pickart, 2009: Multievent analysis of the westerly Greenland tip jet based upon 45 winters in ERA-40. Quart. J. Roy. Meteor. Soc., 135, 19992011.

— vection, and interannual variability. Deep-Sea Res. I, 58, 590614.

van Angelen, J. H., M. R. van den Broeke, and W. J. van de Berg, 2011: Momentum budget of the atmospheric boundary layer over the Greenland ice sheet and its surrounding seas. J. Geophys. Res., 116, D10101, doi:10.1029/2010JD015485.

Van den Broeke, M. R., and N. P. M. Van Lipzig, 2003: Factors controlling the near-surface wind field in Antarctica. Mon. Wea. Rev., 131, 733-743.

and E. Van Meijgaard, 2002: Momentum budget of the East Antarctic atmospheric boundary layer: Results of a regional climate model. J. Atmos. Sci., 59, 3117-3129.

Vellinga, M., and R. A. Wood, 2002: Global climatic impacts of a collapse of the Atlantic thermohaline circulation. Climatic Change, 54, 251-267.

Walter, J. I., E. Jason, S. Tulaczyk, E. E. Brodsky, I. M. Howat, A. H. N. Yushin, and A. Brown, 2012: Oceanic mechanical forcing of a marine-terminating Greenland glacier. Ann. Glaciol., 53, 181-192.

Zhang, Y., D. J. Seidel, J. C. Golaz, C. Deser, and R. A. Tomas, 2011: Climatological characteristics of Arctic and Antarctic surface-based inversions. J. Climate, 24, 5167-5186. 